\title{
Stable isotopes document inter- and intra-specific variation in feeding ecology of nine large southern Procellariiformes
}

\author{
Audrey Jaeger ${ }^{1,2, *}$, Sébastien Jaquemet ${ }^{2,3}$, Richard A. Phillips ${ }^{4}$, Ross M. Wanless ${ }^{5,6}$, \\ Pierre Richard ${ }^{7}$, Yves Cherel ${ }^{1}$ \\ ${ }^{1}$ Centre d'Etudes Biologiques de Chizé, UPR 1934 du CNRS, 79360 Villiers-en-Bois, France \\ ${ }^{2}$ Laboratoire ECOMAR, Université de La Réunion, 15 Avenue René Cassin, BP 7151, 97715 Saint-Denis Cedex, \\ Ile de La Réunion, France \\ ${ }^{3}$ Southern Ocean Group, Zoology and Entomology Department, Rhodes University, Grahamstown 6140, South Africa \\ ${ }^{4}$ British Antarctic Survey, Natural Environment Research Council, High Cross, Madingley Road, Cambridge CB3 0ET, UK \\ ${ }^{5}$ Percy FitzPatrick Institute, DST/NRF Centre of Excellence, University of Cape Town, Rondebosch 7701, South Africa \\ ${ }^{6}$ Seabird Division, BirdLife South Africa, PO Box 7119, Roggebaai 8012, South Africa \\ ${ }^{7}$ Laboratoire Littoral, Environnement et Sociétés, UMR 6250 du CNRS-Université de La Rochelle, 2 rue Olympe de Gouges, \\ 17000 La Rochelle, France
}

\begin{abstract}
Investigating the foraging ecology of seabirds is especially challenging given their wide-ranging movements and the practical difficulties of obtaining unbiased information on their feeding behavior. Despite the development of animal-borne tracking devices, several limitations preclude investigations at the scale of a whole community in a given season or year, and, until recently, during the non-breeding period. Here we analyzed $\delta^{13} \mathrm{C}$ and $\delta^{15} \mathrm{~N}$ in feathers of chicks and adults to investigate inter- and intra-specific variation in the foraging habitat and trophic position of 9 large procellariiform seabirds from 6 southern breeding localities during the breeding and non-breeding periods. Isotopic ratios of each species were generally consistent among different breeding populations, despite the large geographical scale and potential variation in oceanography in surrounding waters. Both spatial and trophic segregation apparently allowed the coexistence of sympatric species in most breeding localities, except at South Georgia, where both $\delta^{13} \mathrm{C}$ and $\delta^{15} \mathrm{~N}$ in chicks showed high overlap among species, probably resulting from the superabundance of alternative food resources during the summer. Low variance in stable isotope ratios among adults in several species indicated high overlap between individuals in feeding habits and trophic levels (i.e. isotopic specialist populations) during the non-breeding period. By contrast, large isotopic variances and the high within- and between-individual components of the trophic niche width suggested that grey-headed and light-mantled sooty albatrosses are generalists. Based on $\delta^{13} \mathrm{C}$, the species that breed in the Southern Ocean can be categorized as residents or subtropical migrants, with the latter including oceanic and neritic subtropical migrants. Albatrosses meet the high energetic challenge of feather synthesis by foraging in different habitats, depending on the length of the non-breeding period. Annual breeders renew their plumage in productive neritic waters in $\sim 4$ mo, whereas biennially breeding species moult in less productive oceanic waters over much longer periods ( 12 to $16 \mathrm{mo})$.
\end{abstract}

KEY WORDS: Albatross $\cdot$ Generalism $\cdot$ Migration $\cdot$ Seabird $\cdot$ Trophic segregation 


\section{INTRODUCTION}

Stable isotope analysis is increasingly used to investigate ecology of individuals, populations, species and communities. Among the various applications is the tracking of large-scale movements of terrestrial and marine animals (Hobson \& Wassenaar 1997, Rubenstein \& Hobson 2004, Phillips et al. 2009, Wiley et al. 2012). Understanding the movements and distributions of organisms allows investigations of fundamental aspects of their ecology and evolutionary history, and is critical for their conservation (Hobson 1999). However, it is especially challenging to obtain information from long-distance migrants, particularly marine species. Large southern-hemisphere procellariiform seabirds forage over thousands of $\mathrm{km}$ from the colony during the breeding season (Weimerskirch et al. 1999, Phillips et al. 2005a, 2006), and can move between ocean basins during the nonbreeding period (Croxall et al. 2005, Phillips et al. 2005b). Procellariiformes, however, include more threatened species than any other order of birds, with evidence for major, long-term declines particularly of populations in the Southern Ocean (Poncet et al. 2006, Delord et al. 2008, Croxall et al. 2012). Knowledge of the distribution and behavior of breeding birds in relation to the marine environment has increased considerably in recent decades following the development of animal-borne electronic devices (Ropert-Coudert \& Wilson 2005). Nevertheless, several limitations (including size and cost) still preclude their use at the scale of a whole community in a given season or year, or, until recently, during the nonbreeding period (Croxall et al. 2005, Phillips et al. 2005b, 2006).

The analysis of natural variation in stable isotope ratios in seabird tissues is a powerful method for investigating seabird foraging ecology, especially during the poorly known non-breeding period (Cherel et al. 2000a, 2006, Hedd \& Montevecchi 2006, Wiley et al. 2012), and at the community scale (Hobson et al. 1994, Forero et al. 2004, Phillips et al. 2009,2011 ). The underlying principle is that the isotopic composition of adult feathers reflects that of their diet during moult, since feather keratin is metabolically inert after synthesis (Hobson \& Clark 1992, Bearhop et al. 2002). Moult occurs primarily during the non-breeding period for most petrels and albatrosses in the Southern Ocean (Warham 1990, 1996, Bridge 2006). In contrast, isotope ratios in the feathers of chicks reflect those in prey delivered by their parents during the chick-rearing period. Hence, comparison of adult and chick feathers allows an assessment of seasonal variation in seabird feeding ecology (Jaeger et al. 2010a). Stable carbon $\left({ }^{13} \mathrm{C} /{ }^{12} \mathrm{C}\right.$, $\left.\delta^{13} \mathrm{C}\right)$ and nitrogen $\left({ }^{15} \mathrm{~N} /{ }^{14} \mathrm{~N}, \delta^{15} \mathrm{~N}\right)$ isotope ratios are used to estimate the consumers' feeding habitat and trophic position, respectively (Newsome et al. 2007). A large-scale sampling program involving the collection of adult and chick feathers from several species during a single field season is relatively straightforward, causes less disturbance and is considerably cheaper than the deployment of tracking devices on a similar number of individuals. At-sea surveys are also useful for investigating at-sea distribution of seabirds (Ainley et al. 2005, Hyrenbach et al. 2007), but provide no information on origin, status or sex of individuals. In contrast, data on stable isotope ratios can be obtained readily from a large number of individuals and species from specific colonies, augmenting and complementing the information obtained from conventional tracking, which usually involves few individuals from a minority of sites. Although several isotopic studies have investigated the feeding ecology and resource partitioning within seabird communities (Hobson et al. 1994, Forero et al. 2004, Phillips et al. 2009) or have compared the same species at different localities (Cherel et al. 2006, Jaquemet et al. 2008, Polito et al. 2011, Wiley et al. 2012), few have combined multi-species and multi-site comparisons (Roscales et al. 2011, Cherel et al. 2013).

Here we compared stable isotope ratios in feathers of individuals $(n=436)$ of 9 large procellariiform species from 6 different breeding localities in the Southern Ocean in order to (1) compare their foraging ecology during the breeding and non-breeding periods, particularly given the more limited information on the latter; (2) investigate potential spatial variation in feeding ecology among birds from different populations, given their wide breeding distribution on isolated island groups in regions with distinct oceanography; and (3) compare the foraging ecology of annual and biennial breeders during the nonbreeding season, given the trade-off between reproduction and feather replacement (Rohwer et al. 2011).

\section{MATERIALS AND METHODS}

Fieldwork was carried out at Marion $\left(47^{\circ} \mathrm{S}, 37^{\circ} \mathrm{E}\right)$, Amsterdam $\left(37^{\circ} \mathrm{S}, 77^{\circ} \mathrm{E}\right)$, Crozet $\left(46^{\circ} \mathrm{S}, 51^{\circ} \mathrm{E}\right)$ and Kerguelen $\left(49^{\circ} \mathrm{S}, 70^{\circ} \mathrm{E}\right)$ Islands in the southern Indian Ocean, and at South Georgia $\left(54^{\circ} \mathrm{S}, 38^{\circ} \mathrm{W}\right)$ and Gough Island $\left(40^{\circ} \mathrm{S}, 9^{\circ} \mathrm{W}\right)$ in the southern Atlantic Ocean (Fig. 1). We define the Southern Ocean as the waters between the Subtropical Front (STF) and Antarctica 


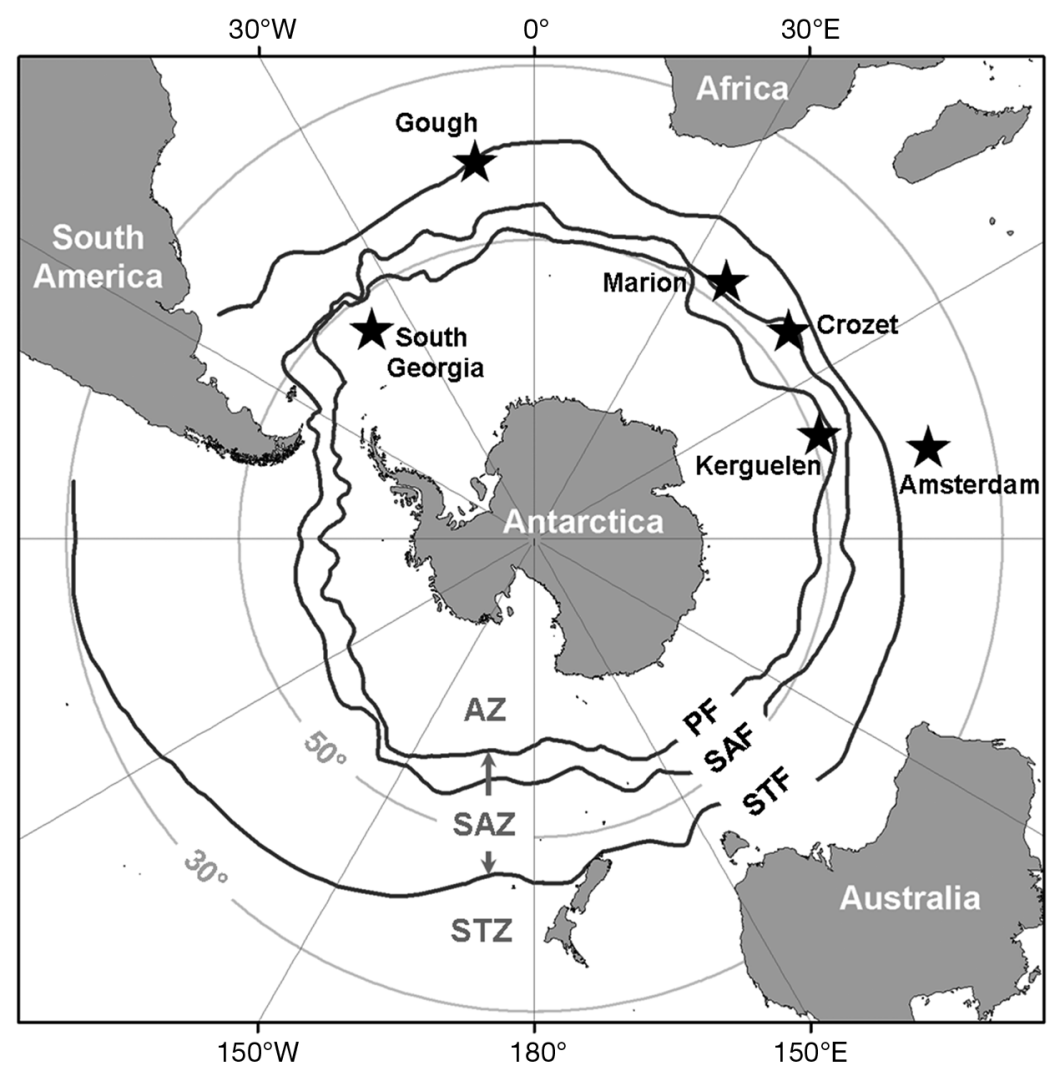

Fig. 1. Sampling sites and main oceanographic fronts and water masses in the Southern Ocean. STF: Subtropical Front; SAF: Subantarctic Front; PF: Polar Front; STZ: Subtropical Zone; SAZ: Subantarctic Zone; AZ: Antarctic Zone
LMSA) breed biennially, while 4 species (WCP, IYNA, AYNA and BBA) breed annually.

For each study species, a few dorsal body feathers were sampled from randomly chosen chicks and breeding adults (see Table 1). The mean isotopic composition of body feathers is not significantly different from that of wing feathers in breeding albatrosses, and the former therefore represent a safe alternative to flight feathers whose collection impairs flight performance (Jaeger et al. 2009). To avoid potential inter-annual variation in stable isotopic ratios linked to a shift in baseline values (Jaeger \& Cherel 2011), as far as possible, all feathers were sampled in the same year. Chick feathers were sampled at the end of the chick-rearing period during the 2005/06 breeding season at Gough and Marion islands, and during the 2004/05 breeding season at the 4 other localities. Adult feathers were all sampled during the 2005/06 breeding season, except those from LMSA at Kerguelen, and some individual AA that were sampled in the 2007/08 season.

(Orsi et al. 1995), and the subantarctic (SAZ) and Antarctic Zones (AZ), as the zones between the Subtropical Front (STF) and Antarctic Polar Front (PF), and between the PF and continental Antarctica, respectively. The Subtropical Zone (STZ) is the oceanic area north of the STF (Fig. 1). All 6 sampling sites were located either within the Southern Ocean or in warmer fringing waters, including 1 Antarctic (South Georgia), 4 subantarctic (Gough, Marion, Crozet, Kerguelen) and 1 subtropical (Amsterdam) localities.

Feathers were collected from adults and chicks of 1 petrel, the white-chinned petrel (WCP) Procellaria aequinoctialis (wingspan $\sim 1.4 \mathrm{~m}$ ); 5 medium-sized albatrosses (wingspan $\sim 2.0$ to $2.5 \mathrm{~m}$ ): the grey-headed (GHA) Thalassarche chrysostoma, Indian yellownosed (IYNA) T. carteri, Atlantic yellow-nosed (AYNA) T. chlororhynchos, black-browed (BBA) T. melanophris, and light-mantled sooty (LMSA) Phoebetria palpebrata; and of 3 great albatrosses (wingspan $\sim 2.7$ to $3.5 \mathrm{~m}$ ), wandering (WA) Diomedea exulans, Amsterdam (AA) D. amsterdamensis and Tristan albatross (TA) D. dabbenena. The great albatrosses (WA, AA and TA) and 2 of the medium-sized species (GHA and
Prior to isotopic analysis, feathers were cleaned of surface lipids and contaminants by immersion in a solution of 2:1 chloroform:methanol for $2 \mathrm{~min}$ in a beaker, followed by 2 successive methanol rinses. Each whole body feather was air dried and cut into small pieces with scissors. Sub-samples were then weighed ( $0.4 \mathrm{mg})$ with a microbalance, packed in tin containers, and nitrogen and carbon isotope ratios were determined by a continuous flow mass spectrometer (Micromass Isoprime) coupled to an elemental analyser (Euro Vector EA 3024). Results are presented in the usual $\delta$ notation relative to Vienna PeeDee Belemnite and atmospheric $\mathrm{N}_{2}$ for $\delta^{13} \mathrm{C}$ and $\delta^{15} \mathrm{~N}$, respectively. Replicate measurements of internal laboratory standards (acetanilide) indicated measurement errors $<0.15$ and $<0.20 \%$ o for $\delta^{13} \mathrm{C}$ and $\delta^{15} \mathrm{~N}$, respectively.

Following Jaeger et al. (2009), variation in feather $\delta^{13} \mathrm{C}$ and $\delta^{15} \mathrm{~N}$ were used to define the degree of specialization in habitat and trophic level, respectively, of adults during the non-breeding period. Isotopic measurements were first made on a single whole body feather per bird to define isotopic specialist 
populations (low trophic niche width, TNW) from generalist populations (high TNW), TNW being the variance among single feathers from all individuals of a given population (Bolnick et al. 2003). In a second step and for generalist populations only, isotopic measurements of 3 additional feathers per bird were used to delineate individuals that were specialists (low within-individual component [WIC], high between-individual component [BIC]) from those that were generalists (high WIC, low BIC). For a given group, WIC is the average variance of 4 individual feathers per bird, and BIC the variation among means of the 4 individual feathers. The relative degree of individual specialization was subsequently considered to be the proportion of TNW explained by within-individual variation: WIC/TNW (this ratio varies from 0 , or maximum variation among individual, to 1 , no variation among individuals; Bolnick et al. 2003).

$\delta^{13} \mathrm{C}$ in particulate organic matter (POM) decreases with latitude in pelagic waters in the Southern Ocean (Trull \& Armand 2001). Carbon isotope ratios in predators are thus indicative of the water masses in which they forage (Cherel \& Hobson 2007, Phillips et al. 2009, Quillfeldt et al. 2010). Due mainly to a slight enrichment of ${ }^{13} \mathrm{C}$ across the food web and to tissue fractionation factors, baseline carbon isotope ratios (isoscapes) of predator foraging areas are better determined using data from predators themselves than from POM, and are specific for each tissue type (Jaeger et al. 2010b). Consequently, to help interpret $\delta^{13} \mathrm{C}$ in feathers sampled from our wide-ranging procellariiform seabirds, we compared these to reference values in 3 control species spanning a latitudinal gradient (see Fig. 2): adult northern rockhopper penguins Eudyptes moseleyi from Amsterdam Island, adult king penguins Aptenodytes patagonicus from Crozet Islands and snow petrel Pagodroma nivea chicks from Adélie Land (high-Antarctica, $66^{\circ} \mathrm{S}$, $140^{\circ} \mathrm{E}$ ). These species are indicative of foraging within the southern STZ (Tremblay \& Cherel 2003), at the PF (Bost et al. 1997) and in the high AZ (Ridoux \& Offredo 1989), respectively (authors' unpubl. data; $\mathrm{n}=12,12$ and $18, \delta^{13} \mathrm{C}=-17.9 \pm 0.2,-21.2 \pm 0.4$ and $-23.4 \pm 0.2 \%$, respectively).

All data were analyzed statistically using $\mathrm{R}$ version 2.11.1. Values are means $\pm \mathrm{SD}$. The isotopic ratios measured in the feathers of the adult albatrosses appear in a previous publication (Cherel et al. 2013), but are presented again in a different context, which is a comparison of foraging ecology, including TNW, between the breeding and nonbreeding periods.

\section{RESULTS}

\section{Breeding and non-breeding isotopic ratios}

$\delta^{13} \mathrm{C}$ and $\delta^{15} \mathrm{~N}$ in feathers of chicks and adults of the 19 populations are shown in Tables $1 \& 2$, respectively. The pattern of seasonal variation in $\delta^{13} \mathrm{C}$ and $\delta^{15} \mathrm{~N}$ differed considerably between species (Fig. 2). Isotopic ratios in feathers from adults and chicks of the different populations of LMSA and GHA were not significantly different ( $t$-test, all $p \geq 0.056)$, except those of LMSA ( $p=0.001$ for $\delta^{13} \mathrm{C}$ ) and GHA ( $<<$ 0.0001 for $\delta^{15} \mathrm{~N}$ ) from South Georgia, whereas they differed greatly for all the other populations of the 7 remaining species (all $\mathrm{p}<0.001$ ).

Hierarchical cluster analyses (Ward's method) performed on carbon and nitrogen isotopic ratios of chick feathers identified 7 distinct clusters, considered here to represent different spatial or trophic niches (Fig. 2a; MANOVA, $\mathrm{p}<0.0001$ ). $\delta^{13} \mathrm{C}$ of Cluster 1 (AA and TA) and Cluster 4 (IYNA and AYNA) did not differ significantly (Tukey's multiple comparison tests, all $\mathrm{p}=$ 0.615). All other clusters had statistically different carbon isotopic ratios (Fig. 3, Tukey's multiple comparison tests, all $\mathrm{p} \leq 0.0001$ ). In terms of $\delta^{15} \mathrm{~N}, 4$ groups of clusters were distinct (Tukey's multiple comparison tests, all $p \leq 0.0001$ ): first group Cluster 1 (AA and TA), second Clusters 2 and 4 (all WA, IYNA and AYNA populations), third Cluster 5 (WCP from Kerguelen and LMSA from South Georgia), and fourth Clusters 3,6 and 7 (all the remaining populations).

Hierarchical cluster analyses (Ward's method) performed on isotopic ratios in adult feathers again identified 7 distinct spatial or trophic niches during the non-breeding period (Fig. 2b; MANOVA, p < 0.0001). Three groups of clusters had statistically different $\delta^{13} \mathrm{C}$ (Fig. 4, Tukey's multiple comparison tests, all $\mathrm{p} \leq$ 0.0001): first group Clusters 6 and 7 (GHA and LMSA populations), second Cluster 2 (BBA from Kerguelen, IYNA and all WA populations) and third Clusters 3, 4 and 5 (all other populations except AA and TA). There were 3 distinct groups in terms of $\delta^{15} \mathrm{~N}$ (Tukey's multiple comparison tests, all $p \leq 0.011$ ): first group Clusters 6 and 7 (GHA and LMSA populations), second Cluster 3 (WCP from South Georgia) and third Clusters 2, 4 and 5 (all other populations except AA and TA). Finally, Cluster 1 (AA and TA) exhibited carbon isotopic ratios intermediate between those of Clusters 3,4 and 5 and those of Cluster 2 (Fig. 4, Tukey's multiple comparison tests, $p \geq 0.244$ and $p=0.062$, respectively), and nitrogen isotopic values intermediate between those of Cluster 3 and those of Clusters 4 and 5 $(p=0.096$ and $p \geq 0.093$, respectively). 
Table 1. $\delta^{13} \mathrm{C}(\%)$ in body feathers of 9 large Procellariiformes from 6 southern hemisphere breeding localities. Values are mean $\pm \mathrm{SD}$ (sample size) and those in the same rows not sharing a common superscript letter are significantly different ( $p<0.05)$. Second row of values for adults indicate the species trophic niche width (TNW). Albatrosses - WA: wandering Diomedea exulans; AA: Amsterdam D. amsterdamensis; TA: Tristan D. dabbenea; GHA: grey-headed Thalassarche chrysostoma; IYNA: Indian yellow-nosed T. carteri; AYNA: Atlantic yellow-nosed T. chlororhynchos; BBA: black-browed T. melanophris; LMSA: lightmantled sooty Phoebetria palpebrata; and WCP: white-chinned petrel Procellaria aequinoctialis

\begin{tabular}{|c|c|c|c|c|c|c|c|}
\hline Species & Status & South Georgia & Kerguelen & Crozet & Marion & Gough & Amsterdam \\
\hline WA & $\begin{array}{l}\text { Chicks } \\
\text { Adults }\end{array}$ & $\begin{array}{c}-19.5 \pm 0.2(10)^{\mathrm{a}, \mathrm{b}} \\
-17.4 \pm 1.1(10)^{\mathrm{a}} \\
1.1\end{array}$ & $\begin{array}{c}-19.3 \pm 0.4(15)^{\mathrm{a}} \\
-16.8 \pm 0.6(12)^{\mathrm{a}} \\
0.3\end{array}$ & $\begin{array}{c}-19.4 \pm 0.4(21)^{\mathrm{a}} \\
-17.1 \pm 0.7(12)^{\mathrm{a}} \\
0.5\end{array}$ & $\begin{array}{c}-19.9 \pm 0.6(12)^{\mathrm{b}} \\
-17.5 \pm 1.0(12)^{\mathrm{a}} \\
0.9\end{array}$ & & \\
\hline AA & $\begin{array}{l}\text { Chicks } \\
\text { Adults }\end{array}$ & & & & & & $\begin{array}{c}-17.7 \pm 0.3(16) \\
-16.2 \pm 0.4(18) \\
0.2\end{array}$ \\
\hline TA & $\begin{array}{l}\text { Chicks } \\
\text { Adults }\end{array}$ & & & & & $\begin{array}{c}-17.2 \pm 0.4(12) \\
-16.4 \pm 0.5(12) \\
0.2\end{array}$ & \\
\hline GHA & $\begin{array}{l}\text { Chicks } \\
\text { Adults }\end{array}$ & $\begin{array}{c}-20.0 \pm 0.6(10)^{\mathrm{a}} \\
-19.2 \pm 1.8(10)^{\mathrm{a}} \\
2.7\end{array}$ & & & $\begin{array}{c}-20.6 \pm 0.4(12)^{\mathrm{b}} \\
-19.5 \pm 1.9(11)^{\mathrm{a}} \\
3.1\end{array}$ & & \\
\hline BBA & $\begin{array}{l}\text { Chicks } \\
\text { Adults }\end{array}$ & $\begin{array}{c}-20.1 \pm 0.8(10)^{\mathrm{a}} \\
-14.8 \pm 1.1(10)^{\mathrm{a}} \\
0.9\end{array}$ & $\begin{array}{c}-18.5 \pm 0.8(18)^{\mathrm{b}} \\
-17.2 \pm 1.1(13)^{\mathrm{b}} \\
1.0\end{array}$ & & & & \\
\hline AYNA & $\begin{array}{l}\text { Chicks } \\
\text { Adults }\end{array}$ & & & & & $\begin{array}{c}-17.7 \pm 0.3(14)^{\mathrm{a}} \\
-15.6 \pm 0.4(12)^{\mathrm{b}} \\
0.1\end{array}$ & \\
\hline IYNA & $\begin{array}{l}\text { Chicks } \\
\text { Adults }\end{array}$ & & & & & & $\begin{array}{c}-17.8 \pm 0.4(12)^{\mathrm{a}} \\
-16.9 \pm 0.6(10)^{\mathrm{a}} \\
0.3\end{array}$ \\
\hline LMSA & $\begin{array}{l}\text { Chicks } \\
\text { Adults }\end{array}$ & $\begin{array}{c}-22.9 \pm 0.3(10)^{\mathrm{a}} \\
-20.6 \pm 2.3(11)^{\mathrm{a}} \\
4.1\end{array}$ & $\begin{array}{c}-21.0 \pm 0.4(15)^{\mathrm{b}} \\
-20.6 \pm 2.7(10)^{\mathrm{a}} \\
9.9\end{array}$ & $\begin{array}{c}-21.3 \pm 0.5(10)^{\mathrm{b}} \\
-20.5 \pm 2.1(10)^{\mathrm{a}} \\
3.9\end{array}$ & $\begin{array}{c}-21.3 \pm 0.5(7)^{\mathrm{b}} \\
-19.9 \pm 2.5(7)^{\mathrm{a}} \\
6.9\end{array}$ & & \\
\hline WCP & $\begin{array}{l}\text { Chicks } \\
\text { Adults }\end{array}$ & $\begin{array}{c}-19.8 \pm 0.8(3)^{\mathrm{a}} \\
-15.3 \pm 0.8(10)^{\mathrm{a}} \\
0.5\end{array}$ & $\begin{array}{c}-22.2 \pm 0.7(14)^{\mathrm{b}} \\
-15.5 \pm 0.7(14)^{\mathrm{a}} \\
0.5\end{array}$ & $\begin{array}{c}-21.2 \pm 0.8(10)^{\mathrm{c}} \\
-14.2 \pm 0.2(10)^{\mathrm{b}} \\
0.1\end{array}$ & & & \\
\hline
\end{tabular}

\section{Trophic niche width in the non-breeding period}

Variances in adult feather $\delta^{13} \mathrm{C}$ and $\delta^{15} \mathrm{~N}$ were used as proxies of the species TNW during the nonbreeding period. Two important features were apparent regarding the TNW of the albatrosses and the white-chinned petrel (Tables 1 \& 2). First, TNW was generally low $\left(0.1-1.1\right.$ and $0.2-0.9 \%$ for $\delta^{13} \mathrm{C}$ and $\delta^{15} \mathrm{~N}$, respectively) regardless of species or population. Second, two exceptions were the large TNW of LMSA and GHA from all breeding localities (2.7-9.9 and $1.5-5.2 \%$ for $\delta^{13} \mathrm{C}$ and $\delta^{15} \mathrm{~N}$, respectively). Following our 2-step protocol (Jaeger et al. 2009), isotope ratios in 3 additional body feathers (for a total of 4 feathers per individual) were measured in each adult GHA to determine the WIC and BIC (Table 3). Individual specialization of LMSA has already been studied at Crozet (Jaeger et al. 2010a) and the results are included in Table 3. The WIC/TNW ratios of LMSA and GHA were moderate, indicating both significant intra- and inter-individual variation.

\section{DISCUSSION}

\section{Breeding-season foraging ecology}

Comparison of $\delta^{13} \mathrm{C}$ and $\delta^{15} \mathrm{~N}$ in feathers of chicks helped to define different foraging habitats and trophic levels for 9 procellariiform species from the Southern Ocean. The first segregating mechanism is spatial. Cluster and other statistical analyses identified 6 groups in terms of chick $\delta^{13} \mathrm{C}$ (Fig. 3). Based on latitudinal variation in $\delta^{13} \mathrm{C}$ of marine organisms in the Southern Hemisphere (e.g. Jaeger et al. 2010b), those 6 groups correspond to 4 main feeding habitats: subtropical oceanic (Clusters 1 and 4), subantarctic (Clusters 2, 6 and 7) and Antarctic waters (Cluster 5), and neritic waters (Cluster 3). Cluster 1 included the species that breed on islands in the subtropics (IYNA and AA) and feed their chicks with prey caught in subtropical oceanic waters, which is in agreement with tracking studies (Pinaud \& Weimerskirch 2007). Interestingly, the $\delta^{13} \mathrm{C}$ of TA and 
Table 2. $\delta^{15} \mathrm{~N}(\%)$ in body feathers of 9 large Procellariiformes from 6 southern hemisphere breeding localities. See Table 1 for details

\begin{tabular}{|c|c|c|c|c|c|c|c|}
\hline Species & Status & South Georgia & Kerguelen & Crozet & Marion & Gough & Amsterdam \\
\hline WA & $\begin{array}{l}\text { Chicks } \\
\text { Adults }\end{array}$ & $\begin{array}{c}15.0 \pm 0.3(10)^{\mathrm{a}} \\
15.4 \pm 0.6(10)^{\mathrm{a}} \\
0.3\end{array}$ & $\begin{array}{c}14.2 \pm 0.4(15)^{\mathrm{b}} \\
15.8 \pm 0.8(12)^{\mathrm{a}} \\
0.5\end{array}$ & $\begin{array}{c}13.9 \pm 0.3(21)^{\mathrm{b}} \\
15.7 \pm 0.7(12)^{\mathrm{a}} \\
0.5\end{array}$ & $\begin{array}{c}14.1 \pm 0.4(12)^{\mathrm{b}} \\
15.4 \pm 0.7(12)^{\mathrm{a}} \\
0.5\end{array}$ & & \\
\hline AA & $\begin{array}{l}\text { Chicks } \\
\text { Adults }\end{array}$ & & & & & & $\begin{array}{c}15.7 \pm 0.3(16) \\
16.7 \pm 0.6(18) \\
0.3\end{array}$ \\
\hline TA & $\begin{array}{l}\text { Chicks } \\
\text { Adults }\end{array}$ & & & & & $\begin{array}{c}16.0 \pm 0.4(12) \\
16.5 \pm 0.7(12) \\
0.5\end{array}$ & \\
\hline GHA & $\begin{array}{l}\text { Chicks } \\
\text { Adults }\end{array}$ & $\begin{array}{c}12.1 \pm 0.4(10)^{\mathrm{a}} \\
10.7 \pm 0.8(10)^{\mathrm{a}} \\
1.5\end{array}$ & & & $\begin{array}{c}11.8 \pm 0.5(12)^{\mathrm{a}} \\
11.7 \pm 1.5(11)^{\mathrm{a}} \\
2\end{array}$ & & \\
\hline BBA & $\begin{array}{l}\text { Chicks } \\
\text { Adults }\end{array}$ & $\begin{array}{c}12.6 \pm 0.7(10)^{\mathrm{a}} \\
15.9 \pm 0.8(10)^{\mathrm{a}} \\
0.6\end{array}$ & $\begin{array}{c}12.9 \pm 0.5(18)^{\mathrm{a}} \\
15.7 \pm 0.6(13)^{\mathrm{a}} \\
0.3\end{array}$ & & & & \\
\hline AYNA & $\begin{array}{l}\text { Chicks } \\
\text { Adults }\end{array}$ & & & & & $\begin{array}{c}14.2 \pm 0.3(14)^{\mathrm{a}} \\
15.8 \pm 0.5(12)^{\mathrm{a}} \\
0.3\end{array}$ & \\
\hline IYNA & $\begin{array}{l}\text { Chicks } \\
\text { Adults }\end{array}$ & & & & & & $\begin{array}{c}14.1 \pm 0.4(12)^{\mathrm{a}} \\
15.4 \pm 0.9(10)^{\mathrm{a}} \\
0.7\end{array}$ \\
\hline LMSA & $\begin{array}{l}\text { Chicks } \\
\text { Adults }\end{array}$ & $\begin{array}{c}11.3 \pm 0.6(10)^{\mathrm{a}} \\
11.8 \pm 2.0(11)^{\mathrm{a}} \\
3.1\end{array}$ & $\begin{array}{c}12.6 \pm 0.4(15)^{\mathrm{b}} \\
12.5 \pm 1.9(10)^{\mathrm{a}} \\
5.2\end{array}$ & $\begin{array}{c}12.4 \pm 0.4(10)^{\mathrm{b}} \\
11.9 \pm 2.1(10)^{\mathrm{a}} \\
3.6\end{array}$ & $\begin{array}{c}12.7 \pm 0.7(7)^{\mathrm{b}} \\
12.1 \pm 2.0(7)^{\mathrm{a}} \\
3.9\end{array}$ & & \\
\hline WCP & $\begin{array}{l}\text { Chicks } \\
\text { Adults }\end{array}$ & $\begin{array}{c}12.9 \pm 1.0(3)^{\mathrm{a}} \\
17.8 \pm 1.0(10)^{\mathrm{a}} \\
0.9\end{array}$ & $\begin{array}{c}11.3 \pm 0.7(14)^{\mathrm{b}} \\
16.1 \pm 0.7(14)^{\mathrm{b}} \\
0.4\end{array}$ & $\begin{array}{c}12.2 \pm 0.7(10)^{\mathrm{a}} \\
16.7 \pm 0.5(10)^{\mathrm{b}} \\
0.2\end{array}$ & & & \\
\hline
\end{tabular}

AYNA that breed on Gough Island, which is close to the northern margin of the subantarctic zone, indicates that both species foraged mainly in subtropical oceanic waters, and not in subantarctic waters, which is corroborated by tracking data from TA (Cuthbert et al. 2005). Cluster 3 included BBA from Kerguelen, which was the only near-exclusive neritic feeder, with the high $\delta^{13} \mathrm{C}$ typical of the Kerguelen shelf (Cherel et al. 2000a,b).

Based on $\delta^{13} \mathrm{C}$, chicks of all the other populations and species are mainly fed on prey taken in subantarctic and northern Antarctic waters, with an apparent latitudinal gradient from north to south as follows: all WA populations, WCP and BBA from South Georgia, the 2 populations of GHA, WCP from Crozet and Kerguelen, and all the LMSA populations. Since adults are known to forage over large areas during chick-rearing, $\delta^{13} \mathrm{C}$ of chick feathers integrate the food collected by both parents, potentially in different water masses. Hence, the relatively high $\delta^{13} \mathrm{C}$ of WA reflect foraging by adults in waters from the STZ to the AZ, with most prey caught in subantarctic waters (Weimerskirch et al. 1993, 1997, $\mathrm{Nel}$ et al. 2002). In contrast, the consistently low $\delta^{13} \mathrm{C}$ of LMSA, GHA and WCP (from the Indian Ocean) indicate that adults forage both in the subantarctic and Antarctic zones, in general accordance with tracking studies (Catard et al. 2000, Nel et al. 2001, Péron et al. 2010). For example, the very low $\delta^{13} \mathrm{C}$ in LMSA chicks from South Georgia exemplifies the southerly location of the island, and that adults favour feeding areas even further to the south during chick-rearing (Phillips et al. 2005a). Results from BBA and WCP from South Georgia are more complex, because their chicks have an apparent subantarctic $\delta^{13} \mathrm{C}$ signature, whereas adults mainly forage in northern Antarctic waters during chickrearing (Phillips et al. 2004, 2006). The most likely explanation of that discrepancy is that each species forages in both oceanic and neritic waters, and the higher baseline isotope signature of the latter increases the mean $\delta^{13} \mathrm{C}$ and $\delta^{15} \mathrm{~N}$ in these consumers; hence their mean values suggest the use of intermediate (i.e. subantarctic) waters (e.g. Cherel \& Hobson 2007, Phillips et al. 2009).

The second segregating mechanism leading to resource partitioning during breeding operates through selection of prey at differing trophic levels, 

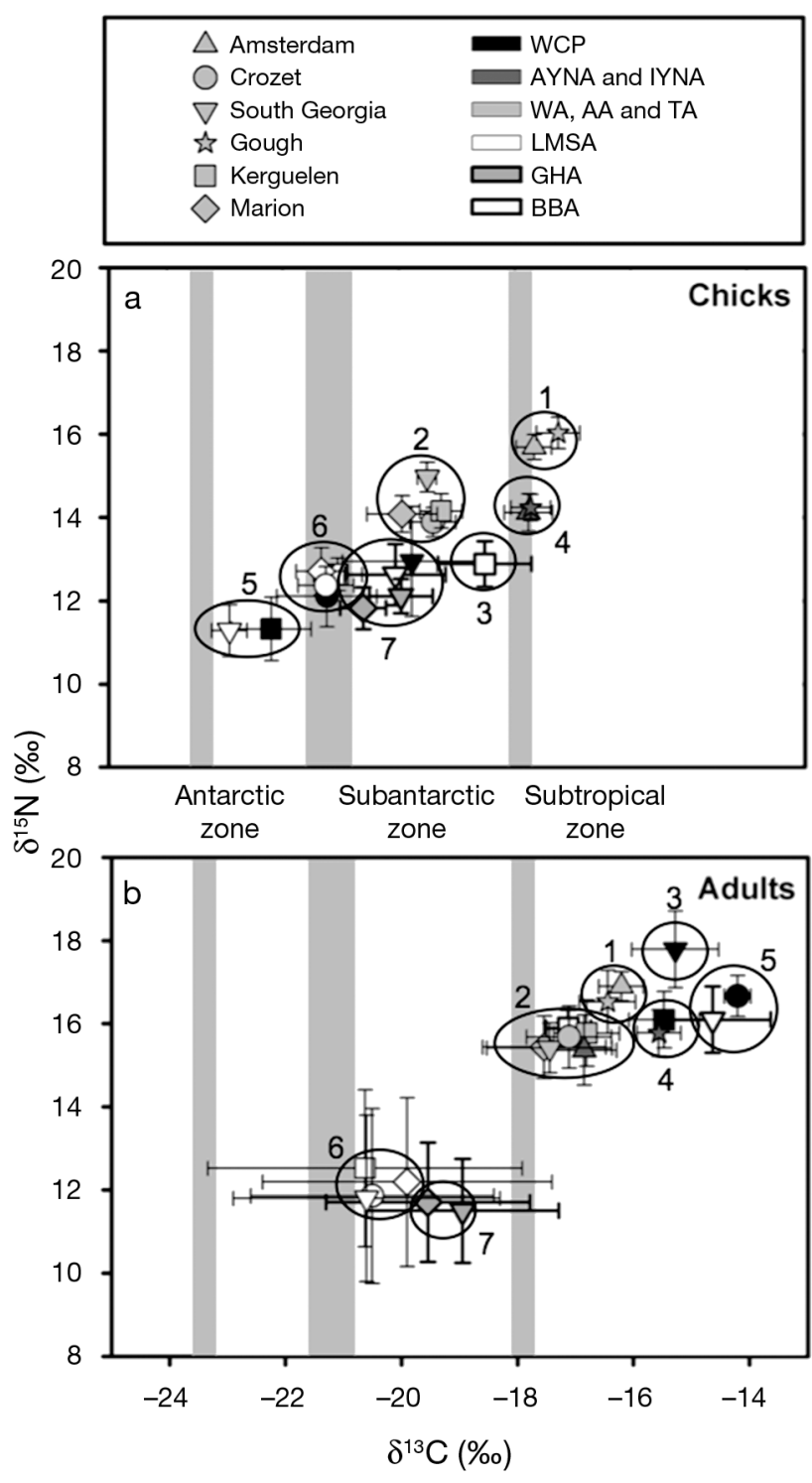

Fig. 2. Mean $\pm \mathrm{SD} \delta^{13} \mathrm{C}$ and $\delta^{15} \mathrm{~N}$ in feathers of (a) chicks and (b) adults of 9 large procellariiform seabirds from 6 southern hemisphere breeding localities. Circles and associated numbers: clusters resulting from hierarchical cluster analyses performed on chick and adult feather isotopic ratios (see text for details). Grey areas: range (mean $\pm \mathrm{SD}$ ) of $\delta^{13} \mathrm{C}$ in feathers of snow petrels, king penguins and northern rockhopper penguins (in this order on the diagrams) that are known to forage in the high-Antarctic Zone, at the Polar Front and in the Subtropical Zone, respectively (see 'Materials and methods'). See Table 1 for bird abbreviations

with the 3 Diomedea albatrosses feeding consistently at a higher trophic level than the other species (Fig. 2a). WA chicks are mainly fed with large squid and fish (Cherel \& Klages 1998), which are likely to be also the main prey of TA and AA, whose diets are poorly-known. By contrast, the food of the other albatrosses and white-chinned petrel is mostly composed

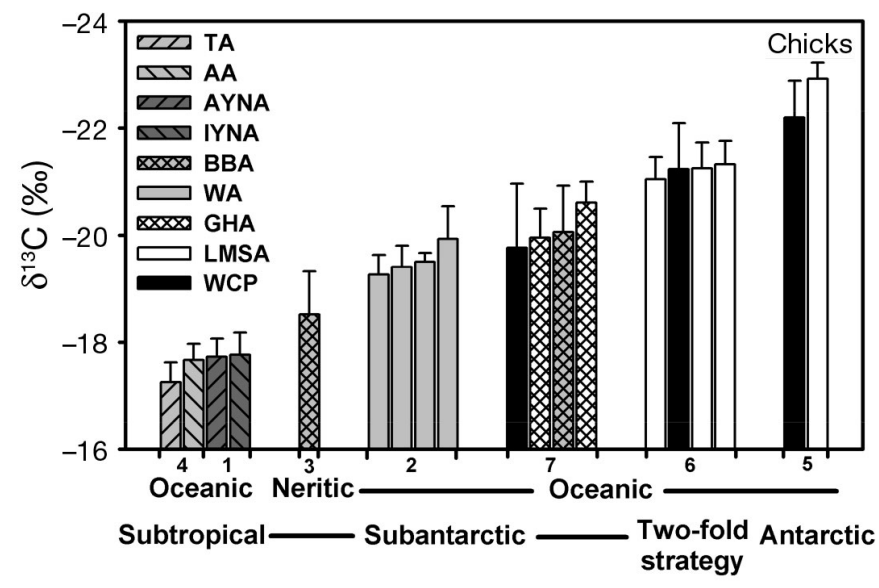

Fig. 3. Histogram of $\delta^{13} \mathrm{C}$ in feathers (mean $\pm \mathrm{SD}$ ) of chicks of 9 large procellariiform seabirds from 6 southern hemisphere breeding localities (each bar a different population) grouped according to feeding habitats/strategies of their parents. Numbers along $x$-axis: cluster numbers from Fig. 2a. Two-fold strategy indicates foraging in both Antarctic and subantarctic zones. See Table 1 for bird abbreviations

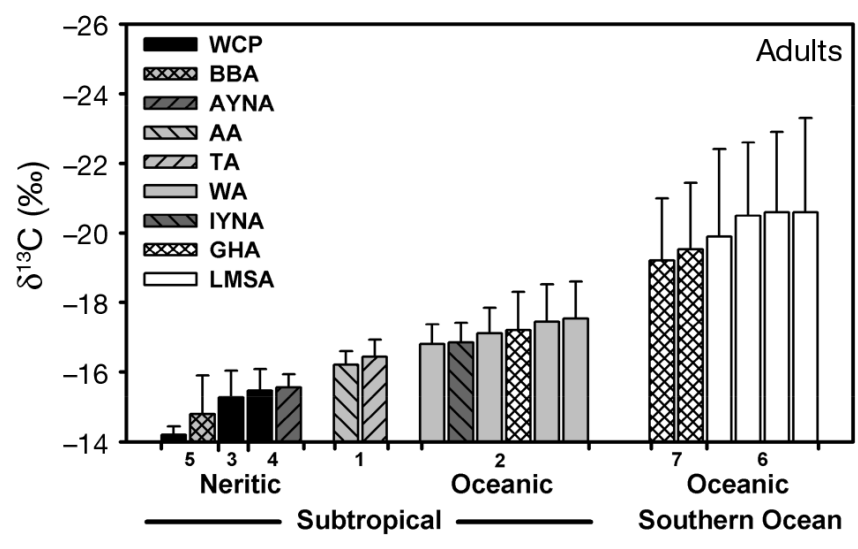

Fig. 4. Histogram of $\delta^{13} \mathrm{C}$ in feathers (mean $\pm \mathrm{SD}$ ) of adults of 9 large procellariiform seabirds from 6 southern hemisphere breeding localities (each bar a different population) grouped according to their feeding habitat during the non-breeding periods. Numbers along $x$-axis: cluster numbers from Fig. $2 b$. See Table 1 for bird abbreviations

of smaller squid, fish and Antarctic krill Euphausia superba (Cherel \& Klages 1998) that have lower nitrogen signatures (Cherel et al. 2008, Anderson et al. 2009). Finally, the higher $\delta^{15} \mathrm{~N}$ of TA, AA, IYNA and AYNA when compared to WA, the other Thalassarche species and LMSA, respectively, are likely to result from higher $\delta^{15} \mathrm{~N}$ baseline levels (that propagate up the food web) in subtropical than subantarctic waters (Quillfeldt et al. 2005, Jaeger et al. 2010b).

During the breeding season, the WCP and most of the albatross species exhibited low variance in their isotopic ratios between the different breeding populations. Why do birds foraging in different ocean 
Table 3. Phoebetria palpebrata and Thalassarche chrysostoma. Trophic niche width (TNW) and its within-individual component (WIC) and between individual component (BIC) calculated from $\delta^{13} \mathrm{C}$ and $\delta^{15} \mathrm{~N}$ in feathers of adult albatrosses from generalist populations (see 'Materials and methods')

\begin{tabular}{|c|c|c|c|c|c|}
\hline Species & $\mathrm{N}$ & $\begin{array}{l}\text { TNW (\%o) } \\
\left(\delta^{13} \mathrm{C} / \delta^{15} \mathrm{~N}\right)\end{array}$ & $\begin{array}{c}\text { WIC (\%o) } \\
\left(\delta^{13} \mathrm{C} / \delta^{15} \mathrm{~N}\right)\end{array}$ & $\begin{array}{c}\text { BIC (\%) } \\
\left(\delta^{13} C / \delta^{15} N\right)\end{array}$ & $\begin{array}{l}\text { WIC/TNW } \\
\left(\delta^{13} \mathrm{C} / \delta^{15} N\right)\end{array}$ \\
\hline \multicolumn{6}{|c|}{ Light-mantled sooty albatross } \\
\hline Crozet & 10 & $3.9 / 3.6$ & $2.6 / 2.1$ & $1.3 / 1.5$ & $0.7 / 0.6$ \\
\hline \multicolumn{6}{|c|}{ Grey-headed albatross } \\
\hline South Georgia & 10 & $2.7 / 1.5$ & $1.4 / 1.3$ & $1.3 / 0.2$ & $0.5 / 0.8$ \\
\hline Marion & 11 & $3.1 / 2.0$ & $1.5 / 1.3$ & $1.6 / 0.7$ & $0.5 / 0.6$ \\
\hline
\end{tabular}

basins retain the same $\delta^{13} \mathrm{C}$ and $\delta^{15} \mathrm{~N}$ signatures? The stratified structure of the main oceanographic features (fronts and water masses) encircling Antarctica (Fig. 1) shapes the Southern Ocean isoscape, thus inducing a well-defined latitudinal — but no obvious longitudinal $-\delta^{13} \mathrm{C}$ gradient. Hence, consumers breeding at different island groups that forage at the same latitudes have broadly similar $\delta^{13} \mathrm{C}$ (Cherel \& Hobson 2007, Jaeger et al. 2010b). The low inter-population variation in $\delta^{15} \mathrm{~N}$ further indicates that each species forages at a very similar trophic position whatever the region (Table 2). However, chick $\delta^{13} \mathrm{C}$ or $\delta^{15} \mathrm{~N}$ generally differed between species at each location, indicating that sympatric breeding species forage in different spatial or trophic niches. A notable exception occurred at South Georgia; GHA, BBA and WCP, which all feed at least partly on krill (Croxall et al. 1997) showed large overlaps in their isotopic ratios (Fig. 2a). This may be explained by reduced competition due to the superabundance of Antarctic krill in the western South Atlantic (Atkinson et al. 2004). The location of South Georgia thus contrasts with that of Marion, Crozet and Kerguelen Islands, where no Antarctic krill occur and where seabirds consequently show greater segregation in terms of foraging strategy (Weimerskirch et al. 1986, Ridoux 1994).

\section{Non-breeding season foraging ecology, TNW and seasonal variations}

$\delta^{13} \mathrm{C}$ and $\delta^{15} \mathrm{~N}$ in feathers of adults indicated that the albatrosses fed in a variety of foraging habitats and at different trophic levels during the nonbreeding period (Cherel et al. 2013). According to $\delta^{13} \mathrm{C}$ there were 3 main feeding habitats: subtropical neritic waters, subtropical oceanic waters, and oceanic waters of the Southern Ocean (Fig. 4). Most of the albatross species sampled in our study leave the Southern Ocean for subtropical neritic (BBA, AYNA,
IYNA) or oceanic (WA, AA, TA) waters, and only 2 species (LMSA, GHA) remain in low latitudes (Cherel et al. 2013). Feather $\delta^{15} \mathrm{~N}$ are more difficult to elucidate because of the considerable variation in baseline $\delta^{15} \mathrm{~N}$ in different ecosystems (Post 2002), but 2 important features arose concerning the nitrogen isotopic ratios of adult feathers. First, as feathers of adult LMSA and GHA had similar $\delta^{13} \mathrm{C}$ and $\delta^{15} \mathrm{~N}$ to those of their chicks, they probably fed on the same diet (a mixture of fish, squid and crustaceans) yearround. Second, adult WA had similar isotopic values to AA and TA chicks, indicating they fed on high trophic level prey, most likely targeting large squid and fish in subtropical waters, during the nonbreeding period.

All WCP populations exhibited high $\delta^{13} \mathrm{C}$ and $\delta^{15} \mathrm{~N}$ values, suggesting foraging in productive neritic waters marked by high $\delta^{13} \mathrm{C}$ and $\delta^{15} \mathrm{~N}$ baselines during the non-breeding period. Band recoveries and tracking studies of WCP from Crozet (Weimerskirch et al. 1985) show that they visit the Benguela upwelling system in winter, and their carbon signatures were identical to that of Cape gannets Morus capensis that forage over the South African shelf all year long (Jaquemet \& McQuaid 2008). WCP from Kerguelen had $\delta^{13} \mathrm{C}$ and $\delta^{15} \mathrm{~N}$ close to those of BBA from South Georgia, indicating foraging in the Benguela upwelling system that is confirmed by a recent study using geolocators (Péron et al. 2010, ACAP 2011). By contrast, WCP from South Georgia, which are known to winter on the Patagonian shelf or in the Humboldt Current off Chile (Phillips et al. 2006), had distinct isotopic values.

Considering TNWs, most species exhibited low values, indicating that they were isotopic specialists, with negligible WIC during the non-breeding period. These populations moult therefore in areas that may be very large but have similar carbon and nitrogen isotopic ratios. By contrast, all LMSA and GHA populations showed large variances in their isotope ratios, which indicate considerable intra-specific differences in foraging habitat. Indeed, the isotopic measurement of several body feathers per individual indicated that LMSA from Crozet are generalists (large TNW and WIC and WIC/TNW $\geq 0.5$ ), reflecting the use of 2 distinct diets and moulting regions: Antarctic krill in the Antarctic zone, and higher trophic level prey in subantarctic waters (Jaeger et al. 2010a). The large variance in isotope ratios of 
LMSA from other populations suggests the situation is similar at South Georgia, Kerguelen and Marion islands. Data from non-breeding GHA from both populations similarly showed large TNW and WIC, and WIC/TNW $\geq 0.5$ (Table 3), indicating that GHA are also generalists. Their feather isotopic signatures indicate that moulting GHA remained mainly in the subantarctic zone ( $60 \%$ of the feathers analyzed), although other body feathers were synthesized in the Antarctic zone (14\%) or the subtropics (26\%).

As in the breeding season, isotopic values in feathers of adults suggest a strong isotopic/trophic segregation between species during the non-breeding period. However, similar $\delta^{13} \mathrm{C}$ and $\delta^{15} \mathrm{~N}$ indicate only that birds forage broadly in the same latitudes, but not necessarily in the same geographical area (region). Comparison of chick and adult $\delta^{13} \mathrm{C}$ within each species confirms 3 annual strategies for procellariiform seabirds breeding in the Southern Ocean (Jaeger et al. 2010a). A few species are 'Southern Ocean residents' (e.g. LMSA and GHA), which forage predominantly all year long within the limits of the Southern Ocean. In contrast, most other species migrate north of the STF, with 'oceanic migrants' (WA) foraging predominantly in subtropical oceanic waters and occasionally visiting coastal waters, and 'neritic migrants' (WCP, BBA and AYNA) primarily wintering over productive shelf waters. Adult AA and TA exhibited carbon and nitrogen isotopic ratios intermediate between subtropical oceanic and neritic migrants. Due to a lack of a suitable isoscape for lower latitude waters, it is difficult to draw conclusions about their non-breeding diet or foraging habitat. It is possible that they share characteristics with the congeneric WA, which showed low seasonal variation in trophic level, feed at a high trophic level during the non-breeding period and visit subtropical oceanic and neritic waters.

\section{Breeding frequency and biological productivity of moulting grounds}

Two constraints shape the pattern of moult in birds. First, the scaling of primary growth rate with body mass explains why feather replacement requires disproportionately more time in large birds (Rohwer et al. 2009), i.e. $~ 3$ non-breeding periods for a complete renewal in albatrosses (Prince et al. 1997). Second, moult is a costly process in terms of energy and nutrients, which in most seabirds means it is not undertaken at the same time as reproduction, which is also particularly demanding (Bridge 2006), although there are some exceptions (Hunter 1984, Spear \& Ainley 1998). Hence, albatrosses replace their feathers at sea during the non-breeding period, which varies in length from $\sim 4$ to 16 mo depending on the breeding frequency and duration of the nesting period for each species. The non-breeding period spans one winter ( $\sim 4 \mathrm{mo}$ ) in most Thalassarche albatrosses that breed annually, a full year $(\sim 12 \mathrm{mo})$ in great albatrosses Diomedea spp. in which the breeding season is unusually prolonged, and a full year plus the following winter ( $16 \mathrm{mo})$ in Phoebetria albatrosses and the minority of Thalassarche species (GHA) that breed biennially. As retention of old, worn feathers may ultimately require albatrosses to skip an extra breeding season (Rohwer et al. 2011), we hypothesise that species with shorter non-breeding periods, and therefore less time available to acquire the energy and nutrients for moult, are more likely to target areas of high resource abundance.

Our isotope results, together with banding and tracking data, indicate that the annual breeders (BBA, AYNA, IYNA and WCP) that are more temporally constrained do indeed moult in productive neritic areas during their short non-breeding season ( 4 mo). Noticeably, BBA from South Georgia, AYNA from Gough and WCP from Crozet and Kerguelen renew their feathers in the Benguela current, and WCP from South Georgia in the Patagonian Shelf, all of which are amongst the most productive marine ecosystems worldwide, with high resource predictability all year round (Perissinotto \& Walker 1998). Large Diomedea albatrosses are biennial breeders, because the length of the breeding period ( 12 mo) together with the need to moult precludes breeding every year. They are less constrained than annual breeders in the choice of moulting grounds because they must inevitably wait $\sim 12$ mo before they can breed again. The last group of albatrosses includes the 2 medium-sized, biennial species, LMSA and GHA, which both spend their long non-breeding period ( 16 mo) over less productive oceanic waters.

Another crucial activity during the non-breeding period is the recovery of body condition following breeding, which is energetically highly demanding. We could hypothesize that the higher the productivity in the non-breeding region, the faster would be the restoration of body condition. Concurrent with feather replacement, species migrating to highly productive areas should therefore restore their body condition in a shorter time, making annual breeding more likely. The ultimate explanation for adoption of a biennial rather than an annual breeding strategy in albatrosses is likely to be the longer duration of the 
chick-rearing period in some species, reflecting the large size of the chick in the great Diomedea albatrosses, and provisioning rate limitations given the distance to feeding grounds (Jouventin \& Dobson 2002). Here we provide evidence that the time available for moult may also have direct implications for habitat selection during the non-breeding period.

Several additional arguments support our hypothesis. Firstly, the biennial breeder and oceanic forager (GHA) replaces fewer feathers during the nonbreeding period than the annual breeder and neritic forager (BBA) (Prince et al. 1997). Secondly, albatrosses renew fewer primaries in years marked by a decrease in marine productivity (Cobley \& Prince 1998). Finally, the breeding frequency, moulting pattern and foraging areas of the 4 Pacific albatrosses of the genus Phoebastria illustrate well the moultbreeding trade-offs in relation to marine productivity. Like their southern counterparts, waved and short-tailed albatrosses ( $P$. irrorata and $P$. albatrus, respectively), which are annual breeders, forage over neritic waters during their short moulting period (Gales 1993, Suryan et al. 2007, ACAP 2011). By contrast, the Laysan and black-footed albatrosses $(P$. immutabilis and $P$. nigripes, respectively) favoured more oceanic waters at that time (Gales 1993, Fisher et al. 2009, ACAP 2011), and they consequently show unusual moulting and breeding patterns by alternating large (long) and small (short) primary moults that determine their breeding frequency, with individuals showing both annual and biennial breeding patterns (Edwards 2008).

Acknowledgements. The authors thank M.-H. Burle, J. Wilson, M. Authier, Y. Charbonnier, L. Denonfoux, G. Dorémus, B. Gangloff, S. Mortreux, Y. Perrot and J.-B. Thiébot for collecting albatross and petrel feathers in the field, and G. Guillou and L. Jouassard for running stable isotope samples. The present work was supported financially and logistically by the program REMIGE - ANR Biodiversité 2005011 (H. Weimerskirch), the Institut Polaire Français Paul Emile Victor (IPEV, programme no. 109, H. Weimerskirch) and the Terres Australes et Antarctiques Françaises (TAAF). S.J. benefited from a NRF post-doctoral contract and from SANAP supports for the fieldwork on Marion Island.

\section{LITERATURE CITED}

ACAP (Agreement on the Conservation of Albatrosses and Petrels) (2011) www.acap.aq

> Ainley DG, Spear LB, Tynan CT, Barth JA, Pierce SD, Glenn Ford R, Cowles TJ (2005) Physical and biological variables affecting seabird distributions during the upwelling season of the northern California Current. Deep-Sea Res II 52:123-143
Anderson ORJ, Phillips RA, McDonald RA, Shore RF, McGill RAR, Bearhop S (2009) Influence of trophic position and foraging range on mercury levels within a seabird community. Mar Ecol Prog Ser 375:277-288

> Atkinson A, Siegel V, Pakhomov E, Rothery P (2004) Longterm decline in krill stock and increase in salps within the Southern Ocean. Nature 432:100-103

> Bearhop S, Waldron S, Votier SC, Furness RW (2002) Factors that influence assimilation rates and fractionation of nitrogen and carbon stable isotopes in avian blood and feathers. Physiol Biochem Zool 75:451-458

Bolnick DI, Svanback R, Fordyce JA, Yang LH, Davis JM, Hulsey CD, Forister ML (2003) The ecology of individuals: incidence and implications of individual specialization. Am Nat 161:1-28

Bost CA, Georges JY, Guinet C, Cherel Y and others (1997) Foraging habitat and food intake of satellite-tracked king penguins during the austral summer at Crozet Archipelago. Mar Ecol Prog Ser 150:21-33

Bridge ES (2006) Influences of morphology and behavior on wing-molt strategies in seabirds. Mar Ornithol 34:7-19

> Catard A, Weimerskirch H, Cherel Y (2000) Exploitation of distant Antarctic waters and close shelf-break waters by white-chinned petrels rearing chicks. Mar Ecol Prog Ser 194:249-261

Cherel Y, Hobson KA (2007) Geographical variation in carbon stable isotope signatures of marine predators: a tool to investigate their foraging areas in the Southern Ocean. Mar Ecol Prog Ser 329:281-287

Cherel Y, Klages N (1998) A review of the food of albatrosses. In: Robertson G, Gales R (eds) Albatross biology and conservation. Surrey Beatty, Chipping Norton, p 113-136

> Cherel Y, Hobson KA, Weimerskirch H (2000a) Using stableisotope analysis of feathers to distinguish moulting and breeding origins of seabirds. Oecologia 122:155-162

Cherel Y, Weimerskirch H, Trouvé C (2000b) Food and feeding ecology of the neritic-slope forager black-browed albatross and its relationships with commercial fisheries in Kerguelen waters. Mar Ecol Prog Ser 207:183-199

> Cherel Y, Phillips RA, Hobson KA, McGill R (2006) Stable isotope evidence of diverse species-specific and individual wintering strategies in seabirds. Biol Lett 2: 301-303

Cherel Y, Ducatez S, Fontaine C, Richard P, Guinet C (2008) Stable isotopes reveal the trophic position and mesopelagic fish diet of female southern elephant seals breeding on the Kerguelen Islands. Mar Ecol Prog Ser 370:239-247

> Cherel Y, Jaeger A, Alderman R, Jaquemet S and others (2013) A comprehensive isotopic investigation of habitat preferences in non-breeding albatrosses from the Southern Ocean. Ecography 36:277-286

> Cobley ND, Prince PA (1998) Factors affecting primary molt in the gray-headed albatross. Condor 100:8-17

> Croxall JP, Prince PA, Reid K (1997) Dietary segregation of krill-eating South Georgia seabirds. J Zool 242:531-556

> Croxall JP, Silk JRD, Phillips RA, Afanasyev V, Briggs DR (2005) Global circumnavigations: tracking year-round ranges of non-breeding albatrosses. Science 307:249-250

Croxall JP, Butchart SHM, Lascelles B, Stattersfield AJ, Sullivan B, Symes A, Taylor P (2012) Seabird conservation status, threats and priority actions: a global assessment. Bird Conserv Int 22:1-34

> Cuthbert R, Hilton GD, Ryan PG, Tuck GN (2005) At-sea distribution of breeding Tristan albatrosses Diomedea dabbenena and potential interactions with pelagic long- 
line fishing in the South Atlantic Ocean. Biol Conserv 121:345-355

> Delord K, Besson D, Barbraud C, Weimerskirch H (2008) Population trends in a community of large Procellariiforms of Indian Ocean: potential effects of environment and fisheries interactions. Biol Conserv 141:1840-1856

Edwards A (2008) Large-scale variation in flight feather molt as a mechanism enabling biennal breeding in albatrosses. J Avian Biol 39:144-151

> Fischer KN, Suryan RM, Roby DD, Balogh GR (2009) Postbreeding season distribution of black-footed and Laysan albatrosses satellite-tagged in Alaska: inter-specific differences in spatial overlap with North Pacific fisheries. Biol Conserv 142:751-760

> Forero MG, Bortolotti GR, Hobson KA, Donázar JA, Bertellotti M, Blanco G (2004) High trophic overlap within the seabird community of Argentinean Patagonia: a multiscale approach. J Anim Ecol 73:789-801

Gales R (1993) Co-operative mechanisms for the conservation of albatross. Australian Nature Conservation Agency \& Australian Antarctic Foundation, Department of Foreign Affairs and Trade, Hobart

> Hedd A, Montevecchi WA (2006) Diet and trophic position of Leach's storm petrel Oceanodroma leucorhoa during breeding and moult, inferred from stable isotope analysis of feathers. Mar Ecol Prog Ser 322:291-301

> Hobson KA (1999) Tracing origins and migration of wildlife using stable isotopes: a review. Oecologia 120:314-326

Hobson KA, Clark RG (1992) Assessing avian diets using stable isotopes I: turnover of ${ }^{13} \mathrm{C}$ in tissues. Condor 94 : 181-188

> Hobson KA, Wassenaar LI (1997) Linking breeding and wintering grounds of neotropical migrant songbirds using stable hydrogen isotopic analysis of feathers. Oecologia 109:142-148

> Hobson KA, Piatt JF, Pitocchelli J (1994) Using stable isotopes to determine seabird trophic relationships. J Anim Ecol 63:786-798

Hunter S (1984) Moult of the giant petrels Macronectes halli and M. giganteus at South Georgia. Ibis 126:119-132

> Hyrenbach KD, Veit RR, Weimerskirch H, Metzl N, Hunt GL Jr (2007) Community structure across a large-scale ocean productivity gradient: marine bird assemblages of the Southern Indian Ocean. Deep-Sea Res I 54:1129-1145

> Jaeger A, Cherel Y (2011) Isotopic investigation of contemporary and historic changes in penguin isotopic niches and carrying capacity of the Southern Indian Ocean. PLoS ONE 6:e16484

Jaeger A, Blanchard P, Richard P, Cherel Y (2009) Using carbon and nitrogen isotopic values of body feathers to infer inter- and intra-individual variations of seabird feeding ecology during moult. Mar Biol 156:1233-1240

> Jaeger A, Connan M, Richard P, Cherel Y (2010a) Use of stable isotopes to quantify seasonal changes of trophic niche and levels of population and individual specialisation in seabirds. Mar Ecol Prog Ser 401:269-277

> Jaeger A, Lecomte V, Weimerskirch H, Richard P, Cherel Y (2010b) Seabird satellite tracking validates the use of latitudinal isoscapes to depict predators' foraging areas in the Southern Ocean. Rapid Commun Mass Spectrom $24: 3456-3460$

> Jaquemet S, McQuaid C (2008) Stable isotope ratios in Cape gannets around the southern coasts of Africa reveal penetration of biogeographic patterns in oceanic signatures. Estuar Coast Shelf Sci 80:374-380
Jaquemet S, Potier M, Cherel Y, Kojadinovic J and others (2008) Comparative foraging ecology and ecological niche of a superabundant tropical seabird: the sooty tern Sterna fuscata in the southwest Indian Ocean. Mar Biol 155:505-520

Jouventin P, Dobson FS (2002) Why breed every year? The case of albatrosses. Proc R Soc Lond B Biol Sci 269: 1955-1961

> Nel DC, Lutjeharms JRE, Pakhomov EA, Ansorge IJ, Ryan PG, Klages NTW (2001) Exploitation of mesoscale oceanographic features by gray-headed albatrosses Thalassarche chrysostoma in the southern Indian Ocean. Mar Ecol Prog Ser 217:15-26

> Nel DC, Ryan PG, Nel JL, Klages NTW, Wilson RP, Robertson G (2002) Foraging interactions between wandering albatrosses Diomedea exulans breeding on Marion Island and long-line fisheries in the southern Indian Ocean. Ibis 144:E141-E154

Newsome SD, Martinez del Rio C, Bearhop S, Phillips DL (2007) A niche for isotopic ecology. Front Ecol Environ 5: 429-436

> Orsi AH, Whitworth T III, Nowlin WD (1995) On the meridional extent and fronts of the Antarctic Circumpolar Current. Deep-Sea Res I 42:641-673

Perissinotto R, Walker DR (1998) Marine ecosystems and their productivity. In: Ambasht RS (ed) Modern trends in ecology and environment. Backhuys, Leiden, p 131-153

> Péron C, Delord K, Phillips R, Charbonnier Y, Marteau C, Louzao M, Weimerskirch H (2010) Seasonal variations in oceanographic habitat and behaviour of white-chinned petrels Procellaria aequinoctialis from Kerguelen Island. Mar Ecol Prog Ser 416:267-284

> Phillips RA, Silk JRD, Phalan B, Catry P, Croxall JP (2004) Seasonal sexual segregation in two Thalassarche albatross species: competitive exclusion, reproductive role specialization or trophic niche divergence? Proc R Soc Lond B Biol Sci 271:1283-1291

> Phillips RA, Silk JRD, Croxall JP (2005a) Foraging and provisioning strategies of the light-mantled sooty albatross at South Georgia: competition and co-existence with sympatric pelagic predators. Mar Ecol Prog Ser 285: 259-270

> Phillips RA, Silk JRD, Croxall JP, Afanasyev V, Bennett VJ (2005b) Summer distribution and migration of nonbreeding albatrosses: individual consistencies and implications for conservation. Ecology 86:2386-2396

Phillips RA, Silk JRD, Croxall JP, Afanasyev V (2006) Yearround distribution of white-chinned petrels from South Georgia: relationships with oceanography and fisheries. Biol Conserv 129:336-347

> Phillips RA, Bearhop S, McGill RAR, Dawson DA (2009) Stable isotopes reveal individual variation in migration strategies and habitat preferences in a suite of seabirds during the non-breeding period. Oecologia 160:795-806

> Phillips RA, McGill RAR, Dawson DA, Bearhop S (2011) Sexual segregation in distribution, diet and trophic level of seabirds: insights from stable isotope analysis. Mar Biol 158:2199-2208

Pinaud D, Weimerskirch H (2007) At-sea distribution and scale-dependent foraging behaviour of petrels and albatrosses: a comparative study. J Anim Ecol 76:9-19

Polito MJ, Lynch HJ, Naveen R, Emslie SD (2011) Stable isotopes reveal regional heterogeneity in the pre-breeding distribution and diets of sympatrically breeding Pygoscelis spp. penguins. Mar Ecol Prog Ser 421:265-277 
Poncet S, Robertson G, Phillips RA, Lawton K, Phalan B, Trathan PN, Croxall JP (2006) Status and distribution of wandering, black-browed and grey-headed albatrosses at South Georgia. Polar Biol 29:772-781

Post DM (2002) Using stable isotopes to estimate trophic position: models, methods, and assumptions. Ecology 83: 703-718

Prince PA, Weimerskirch H, Huin N, Rodwell S (1997) Molt, maturation of plumage and ageing in the wandering albatross. Condor 99:58-72

Quillfeldt P, McGill RAR, Furness RW (2005) Diet and foraging areas of Southern Ocean seabirds and their prey inferred from stable isotopes: review and case study of Wilson's storm-petrel. Mar Ecol Prog Ser 295: 295-304

Quillfeldt P, Masello JF, McGill RAR, Adams M, Furness RW (2010) Moving polewards in winter: a recent change in the migratory strategy of a pelagic seabird? Front Zool 7: 15

Ridoux V (1994) The diets and dietary segregation of seabirds at the subantarctic Crozet Islands. Mar Ornithol 22: $1-192$

Ridoux V, Offredo C (1989) The diets of five summer breeding seabirds in Adélie Land, Antarctica. Polar Biol 9: 137-145

Rohwer S, Ricklefs RE, Rohwer VG, Copple MM (2009) Allometry of the duration of flight feather molt in birds. PLoS Biol 7:e1000132

Rohwer S, Viggiano A, Marzluff JM (2011) Reciprocal tradeoffs between moult and breeding in albatrosses. Condor 113:61-70

Ropert-Coudert Y, Wilson RP (2005) Trends and perspectives in animal-attached remote sensing. Front Ecol Environ 3:437-444

Roscales JL, Gomez-Diaz E, Neves V, Gonzalez-Solis J (2011) Trophic versus geographic structure in stable isotope signatures of pelagic seabirds breeding in the northeast Atlantic. Mar Ecol Prog Ser 434:1-13

Rubenstein DR, Hobson KA (2004) From birds to butterflies: animal movement patterns and stable isotopes. Trends Ecol Evol 19:256-263

Spear LB, Ainley DG (1998) Morphological differences rela-

Editorial responsibility: Hans Heinrich Janssen,

Oldendorf/Luhe, Germany tive to ecological segregation in petrels (family: Procellariidae) of the Southern Ocean and Tropical Pacific. Auk 115:1017-1033

- Suryan RM, Dietrich KS, Melvin EF, Balogh GR, Sato F, Ozaki K (2007) Migratory routes of short-tailed albatrosses: use of exclusive economic zones of North Pacific Rim countries and spatial overlap with commercial fisheries in Alaska. Biol Conserv 137:450-460

Tremblay Y, Cherel Y (2003) Geographic variation in the foraging behaviour, diet and chick growth of rockhopper penguins. Mar Ecol Prog Ser 251:279-297

Trull TW, Armand L (2001) Insights into Southern Ocean carbon export from the $\delta^{13} \mathrm{C}$ of particles and dissolved inorganic carbon during the SOIREE iron release experiment. Deep-Sea Res II 48:2655-2680

Warham J (1990) The petrels: their ecology and breeding systems. Academic Press, London

Warham J (1996) The behaviour, population biology and physiology of the petrels. Academic Press, London

> Weimerskirch H, Jouventin P, Mougin JL, Stahl JC, Van Beveren M (1985) Banding recoveries and the dispersal of seabirds breeding in French Austral and Antarctic Territories. Emu 85:22-33

Weimerskirch H, Jouventin P, Stahl JC (1986) Comparative ecology of the six albatross species breeding on the Crozet Islands. Ibis 128:195-213

Weimerskirch H, Salamolard M, Sarrazin F, Jouventin P (1993) Foraging strategy of wandering albatrosses through the breeding season: a study using satellite telemetry. Auk 110:325-342

Weimerskirch H, Cherel Y, Cuénot-Chaillet F, Ridoux V (1997) Alternative foraging strategies and resource allocation by male and female wandering albatrosses. Ecology 78:2051-2063

- Weimerskirch H, Catard A, Prince PA, Cherel Y, Croxall JP (1999) Foraging white-chinned petrels Procellaria aequinoctialis at risk: from the tropics to Antarctica. Biol Conserv 87:273-275

Wiley $\mathrm{AE}$, Welch AJ, Ostrom $\mathrm{PH}$, James HF and others (2012) Foraging segregation and genetic divergence between geographically proximate colonies of a highly mobile seabird. Oecologia 168:119-130

Submitted: November 12, 2012; Accepted: June 6, 2013 Proofs received from author(s): August 19, 2013 